\title{
Liquid Smoke as Fat Protector and Its Effect on Rumen Fermentation Characteristics and Microbial Activity
}

\author{
N. C. Tiven ${ }^{\mathrm{a}, *}$, L. Hartati $^{\mathrm{b}}$, \& T. M. Simanjorang ${ }^{\mathrm{c}}$ \\ ${ }^{a}$ Department of Animal Husbandry, Faculty of Agriculture, Pattimura University \\ Jalan Ir. M. Putuhena Kampus Unpatti-Poka, Ambon 97233, Indonesia \\ ${ }^{b}$ Department of Animal Science, Agriculture Faculty, Tidar University \\ Jalan Kapten S. Parman 39 Potrobangsan, Magelang Utara, Jawa Tengah 56116, Indonesia \\ 'Postgraduate Program at the Faculty of Agriculture, Universitas Gadjah Mada \\ Jalan Flora Bulaksumur Yogyakarta 55281, Indonesia \\ ${ }^{*}$ Corresponding author: nafly_tiven@yahoo.co.id \\ (Received 29-02-2020; Revised 30-05-2020; Accepted 12-06-2020)
}

\begin{abstract}
This study was conducted to determine the effect of liquid smoke as a fat protector on unsaturated fatty acids (UFAs) and its effect on rumen fermentation characteristics and microbial activity. Crude palm oil (CPO) was mixed with Prosteo skim milk (1:2), then divided into three treatments i.e., crude palm oil without protection by liquid smoke as a control (P0), crude palm oil protected by $2.5 \%$ of liquid smoke (P1), and crude falm oil protected by $5.0 \%$ of liquid smoke (P2). For in vitro testing, $300 \mathrm{mg}$ of the feed substrate (elephant grass and bran with the ratio of $60: 40$ ) was added with $5 \%$ of each crude palm oil preparation of $\mathrm{P} 0, \mathrm{P} 1$, and $\mathrm{P} 2$ and put in a fermentor syringe. Then, $30 \mathrm{~mL}$ of the mixture of rumen fluid and buffer-minerals solution (1:2) was added into each syringe fermentor and flushed with $\mathrm{CO}_{2}$. The fermentor syringes were incubated in a water bath at $39^{\circ} \mathrm{C}$ for 48 hours. Variables measured were fatty acid composition, fermentation characteristics, and rumen microbial activity. The data were analyzed by the analysis of variance with a completely randomized design. The results showed that the protection of CPO with liquid smoke in P1 and P2 groups decreased saturated fatty acids (SFAs), but increased $(\mathrm{p}<0.01)$ monounsaturated fatty acids (MUFAs), polyunsaturated fatty acids (PUFAs), and CMCase activity. Protection of CPO with $2.5 \%$ of liquid smoke (P1) significantly increased $(\mathrm{p}<0.01)$ fermentation characteristics $\left(\mathrm{NH}_{3}\right.$ content and $\mathrm{pH}$ ). It can be concluded that the use of $2.5 \%$ of liquid smoke has a better effect on feed fats protection, because it can reduce hydrogenation, increase UFAs, and has no negative effects on fermentation characteristics and microbial activity.
\end{abstract}

Keywords: hydrogenation; liquid smoke; rumen fermentation characteristics; rumen fluid fatty acids; rumen microbial activity

\section{INTRODUCTION}

Feeding ruminants with fats that contain high unsaturated fatty acids (UFAs), the benefits of the UFAs will be disappeared, because most UFAs, especially polyunsaturated fatty acids (PUFAs) in the feed will be hydrogenated by rumen microbes (Abuelfatah et al., 2016) and converted into saturated fatty acids.

Microbial biohydrogenation is the process of converting unsaturated fatty acids into more saturated end products by rumen microbes (Li et al., 2012), especially stearic acid (C18:0) (Harfoot \& Hazlewood, 1997). As a result, linoleic acid (C18: $2 \mathrm{n}-6)$ and linolenic acid (C18: $3 n-3)$ in the feed are hydrogenated by rumen microbes (70\%-95\% and $85 \%-100 \%$, respectively) into MUFA and SFA and only a small portion (about $10 \%$ of the feed consumed) enters the fat tissue (Nieto \& Ros, 2012). High SFAs cause meat fat to be harder with high cholesterol levels, which causes people to avoid eating meat because meat with high SFA and cholesterol can trigger cardiovascular disease (CVD) (Soliman, 2018; Liu et al., 2019).

As a result of hydrogenation, the use of UFAs in ruminant feed is limited (Tran et al., 2017). The use of high fat in feed is toxic to rumen microbes that eventually inhibits fiber digestion and reduces feed intake (Behan et al., 2019). This condition is caused by the covering of the surface of the feed and wrapping of the rumen microbial cells by the UFAs that eventually inhibit the penetration of enzymes into the feed.

One way to reduce the hydrogenation of UFAs and maximize the use of high UFAs is to protect feed fat from hydrogenation with a technical formaldehyde. The mechanism is that the aldehyde from formaldehyde will join or form strong bonds with amino acids from a protein source, thus protecting the fat inside. These bonds that protect fats inside are resistant to neutral $\mathrm{pH}$ in the rumen $(\mathrm{pH}$ 6-7) but the bonds will be disrupted at the acidic $\mathrm{pH}$ in the omasum $(\mathrm{pH}$ 2-3) that eventually release the fat and UFA so that it can be 
absorbed in the small intestine (Scott et al., 1970). The protection of crude palm oil (CPO) as a source of UFAs in sheep rations using formaldehyde can increase UFAs composition and microbial activity in vitro (Tiven et al., $2011 \mathrm{a}, 2011 \mathrm{~b})$. As much as 3\% of CPO was protected by $2 \%$ formaldehyde and can reduce hydrogenation of UFA and increase UFAs concentrations in the blood and meat (Tiven et al., 2013), and gives more advantage to feed conversion aspect (Tiven et al., 2015). However, this good result cannot yet be applied because formaldehyde is a dangerous and carcinogenic material that can cause cancer (Swenberg, 2013).

The research using natural aldehydes present in plants as fat protectors, including citronellal in Kaffir lime (Citrus hystrix) leaves powder increased UFAs in vitro (Tiven, 2017) and increased PUFAs, protein, and fat, but reduced cholesterol content in lamb meat (Tiven et al., 2016). These results cannot yet be applied to ruminants, because it requires a lot of cinnamon powder and kaffir lime leaves which are very numerous, making it less economical and polluting as well as changing the color of the ration.

The present research used liquid smoke as a protector of feed fat. Liquid smoke contains natural aldehydes in its carbonyl component (Montazeri et al., 2013) that can be used to replace technical formaldehyde. Liquid smoke can be used in animal feed because it is an antioxidant (Hadanu \& Apituley, 2016), can prevent the growth of fungi and bacteria, prevent free radicals, so that nutrient contents of feed does not decrease (Hatta et al., 2018). Liquid smoke is safe for consumption, and it can affect the flavor and product storage time because carbonyl will react to protein with a relatively strong bond (Anggraini \& Yuniningsih, 2017).

Protection of feed fats using liquid smoke has never been done before, so it has a very high novelty value. In line with that, this study was conducted to determine the effect of liquid smoke as a fat protector on unsaturated fatty acids (UFAs) and its effect on rumen fermentation characteristics and microbial activity. Protection of feed fats using liquid smoke is expected to reduce the hydrogenation of UFAs, increase UFAs, but do not negatively affect fermentation characteristics and rumen microbial activity so that it can be applied in vivo.

\section{MATERIALS AND METHODS}

\section{Fat Protection by Liquid Smoke}

Before being used, CPO as a source of feed fat was analyzed to get the fat profile (iodine value, saponification value, acid value, and fatty acid composition by following the protocols of Dymińska et al. (2017) and Nielsen (2019). CPO was mixed with Prosteo skim milk (at the ratio of 1:2) evenly manually. Then the liquid smoke was added into the mixture of CPO according the treatment: P0 (CPO without protection by liquid smoke); P1 (CPO protected by $2.5 \%$ of liquid smoke); and P2 (CPO protected by $5 \%$ of liquid smoke), and the mixture was then mixed evenly manually.

\section{In Vitro Gas Test}

As much as $300 \mathrm{mg}$ of the feed substrate and 5\% (15 $\mathrm{mg}$ ) of CPO mixture with $0 \%, 2.5 \%$, or $5 \%$ liquid smoke according to the treatments were put into fermentor syringes. Then, $30 \mathrm{~mL}$ of a mixture of rumen fluid and buffer-minerals solution $(1: 2 \mathrm{v} / \mathrm{v})$ was added and the syringe was closed with a piston according to Tilley \& Terry (1963). The rumen fluid, as the microbial source, was obtained from two local female sheep by the trocar method (Tiven, 2012). The syringe flowed with $\mathrm{CO}_{2}$ gas so that the atmosphere becomes anaerobic, then the rubber pipe at the end of the syringe was clipped, then the syringe was put into water bath at the temperature of $39^{\circ} \mathrm{C}$ to be incubated for 48 hours. During the fermentation process, gas production was recorded at intervals of $0,2,4,6,8,12,24$, and 48 hours (Menke \& Steingass, 1988). After the fermentation process was stopped, the fermentor syringe containing fermentation fluid was divided into two groups, namely (1) for testing fatty acids and (2) for testing fermentation characteristics and microbial activity.

\section{Fatty Acid Test}

After the incubation process was completed, the fermentation fluid in the syringe was poured into a 100 $\mathrm{mL}$ Erlenmeyer for the measurement of fatty acids according to Park \& Goins (1994), modified. The process of fat extraction in fermented liquid obtained from the fermentation fluid was conducted by adding $20 \mathrm{~mL}$ of a mixture of chloroform-methanol (2:1) and let stand until the formation of two layers. The top layer (supernatant) was removed, while the lower layer (sediment) was taken and filtered into a $50 \mathrm{~mL}$ test tube through filter paper. A total of $4 \mathrm{~mL}$ of $0.88 \% \mathrm{NaCl}$ was added to the test tube and shaken out and then allowed to stand until two layers were formed again. The top layer was removed and the bottom layer was filtered again into a test tube through anhydrous $\mathrm{Na}_{2} \mathrm{SO}_{4}$ on filter paper to bind water that might still exist. The test tube was drained with N2 to remove chloroform.

The remaining fat in the test tube was methylated. A total of $1 \mu \mathrm{L}$ of the supernatant (top layer) of the methylation result was injected into the gas chromatography Shimadzu GC 2010 Plus 2017, with Helium as a carrier gas with a flow rate of $40 \mathrm{~mL} / \mathrm{min}$ and as a burning gases were hydrogen and oxygen. The column used was the capillary column Qtx-wax with a length of 30 meters and an inner diameter of $0.25 \mathrm{~mm}$ (Nielsen, 2019). The fatty acid composition was calculated with relative percentages (Nugraheni et al., 2015):

Fatty acid $=[$ Area of fatty acid / (Total area of sample Area of solvent)] x $100 \%$

\section{Fermentation Characteristics and Microbial Activity Test}

Fermentation characteristics tested were $\mathrm{NH}_{3}$, VFA, and rumen fluid $\mathrm{pH}$, while microbial activity tested were CMCase activity and microbial protein. After the 
fermentation process was stopped, the fermentation fluid was centrifuged at a speed of $500 \mathrm{~g}$ for 15 minutes to separate the feed particles, then the filtrate is centrifuged again with a speed of $10,000 \mathrm{~g}$ for 15 minutes to separate microbial sediment. The filtrate was taken for the determination of CMCase activity based on the amount of reducing sugar formed from the CMC substrate (Halliwel et al., 1985), expressed in the activity of specific enzymes with the measuring protein enzyme levels using the Lowry method, $\mathrm{N}_{-} \mathrm{NH}_{3}$ (Weatherburn, 1967), total VFA by gas chromatography method (Jayanegara et al., 2016), and pH (Suharti et al., 2018). Microbial sediment was dissolved by adding $0.5 \mathrm{~mL}$ of $1 \mathrm{~N} \mathrm{NaOH}$ and then heated at $90^{\circ} \mathrm{C}$ for 10 minutes. After dissolving, distilled water was added to reach a total volume of $1 \mathrm{~mL}$. The determination of the amount of biomass was based on the protein content of microbial cells by the Lowry method by using spectrophotometer.

The $\mathrm{N}_{-\mathrm{NH}_{3}}$ test was carried out according to Weatherburn (1967). A total of 1-20 $\mu \mathrm{L}$ of the filtrate were entered into the test tube, added with $5.0 \mathrm{~mL}$ of reagent $\mathrm{A}$ ( $5 \mathrm{~g}$ of phenol and $25 \mathrm{mg}$ of sodium nitroprusside) and reagent $\mathrm{B}$ (2.5 $\mathrm{g}$ of sodium hydroxide and $4.2 \mathrm{~mL}$ of sodium hypochloride). Fortex each test tube, then incubated for 30 minutes at room temperature and measured on a spectrophotometer with a wavelength of $625 \mathrm{~nm}$. As a standard solution, $14.4 \mathrm{mg}$ ammonium sulfate dissolved in distilled water to $100 \mathrm{~mL}$ volume, 1 $\mu \mathrm{N}$ solution contains $0.3 \mu \mathrm{g} \mathrm{N}-\mathrm{NH}_{3}$.

The VFA test was carried out according to Doreau et al. (1993). The filtrate was centrifuged $3000 \mathrm{~g}$ for 15 minutes, then $0.2 \mathrm{~mL}$ of filtrate was added with $1 \mathrm{~mL}$ of metaphosphoric acid. The filtrate was centrifuged again with $9000 \mathrm{~g}$ for 10 minutes to measure the levels of VFA using gas chromatography (GC) Shimadzu GC 2010 Plus 2017.

CMCase activity was carried out according to Halliwel et al. (1985). The filtrate about 13,000 g was centrifuged for 15 minutes for determination of CMCase activity. All tubes were incubated at $39^{\circ} \mathrm{C}$ for 45 minutes. The enzyme activity was stopped by adding a solution consisting of $1 \mathrm{~mL}$ of carbonate cyanide, 0.2 $\mathrm{mL}$ of sodium carbonate, and $2 \mathrm{~mL}$ of $0.05 \%$ potassium ferricyanide. The contents of the tube are homogenized with vortices. All tubes were heated in boiling water for 30 minutes, then the results obtained were read by a spectrophotometer at a wavelength of $420 \mathrm{~nm}$. The standard graph was made using glucose levels of 1.39$19.44 \mathrm{mg} / \mathrm{mL}$ in a sample of $1.8 \mathrm{~mL}$. The tube containing glucose was treated the same as the steps above so that absorbance data were obtained. The CMC-ase activity was calculated based on a formula: The absorbance unit $=(B L-E S)-(B L-E)-(B L-S)$, where ES was enzyme and sample, E was enzyme, $\mathrm{S}$ was sample, and BL was blank. The result from the absorbance unit (Y) is entered into the regression equation of the standard glucose graph equation, $\mathrm{Y}=0.0303 \mathrm{x}+0.0076$ to determine the level of CMC-acid.

Microbial protein was carried out according to Plummer (1987). The precipitate from the centrifugation of $13,000 \mathrm{~g}$ was used to measure the microbial protein content using the Lowry method. A sample of
$0.5 \mathrm{~mL}$ was put into a test tube then added with 2.5 mL of Lowry I solution $\left(2 \% \mathrm{Na}_{2} \mathrm{CO}_{3}\right.$ in $0.1 \mathrm{NaOH}, 2 \%$ sodium tartrate, $1 \% \mathrm{CuSO}_{4} 5 \mathrm{H}_{2} \mathrm{O}$, then mixed with a ratio of 100: 1:1) and let stand at room temperature for 10 minutes. The sample was then added with $0.25 \mathrm{~mL}$ of Lowry II solution ( $1 \mathrm{~N}$ Folin ciocalteceau, $\mathrm{H}_{2} \mathrm{O}$, mixed with a ratio of 1:1), and let stand at room temperature for 30 minutes, then read using a spectrophotometer at a wavelength of $750 \mathrm{~nm}$. Standard charts were made using Bovine Serum Albumin (BSA) with levels of 0.00$0.27 \mathrm{mg} / \mathrm{mL}$. From the absorbance $(Y)$ of the sample obtained, it will be known the dissolved protein content $(X)$ by entering into the regression equation from the albumin standard graph equation: $\mathrm{Y}=2.1706 \mathrm{x}+0.03281$.

\section{Statistical Analysis}

The data obtained were statistically tested using analysis of variance used completely randomized design, with three treatments, namely $\mathrm{CPO}$ without protection by liquid smoke (P0), CPO protected by $2.5 \%$ of liquid smoke (P1), and CPO protected by $5.0 \%$ of liquid smoke (P2) with five replications. Significant treatment was tested further by Duncan's New Multiple Range Test (Gupta et al., 2016).

\section{RESULTS}

\section{Lipid Profile and Fatty Acid Composition of Crude Palm Oil (CPO) before and after being Protected by Liquid Smoke}

The qualities of CPO were determined by measuring the fat profile (iodine value, saponification value, acid value), which are presented in Table 1 . The iodine value, saponification value, acid value, and peroxide value of CPO used in this research were $36.27 \mathrm{~g} \mathrm{I}_{2} / 100 \mathrm{~g}$, $182.84 \mathrm{mg} \mathrm{KOH} / \mathrm{g}$, $6.98 \mathrm{mg} \mathrm{KOH} / \mathrm{g}$, and $0.30 \mathrm{mg} \mathrm{KOH} / \mathrm{g}$, respectively. The fatty acids composition of $\mathrm{CPO}$ used in this study with the contents of SFA, MUFA, and PUFA were $60.42 \%, 30.21 \%$, and $8.41 \%$, respectively.

Fatty acid composition of CPO before and after being protected by liquid smoke (before fermentation) are presented in Table 2 . The results shows that there is no significant effect (increase or decrease) of the treatments to the fatty acis contents.

\section{The Fatty Acid Composition of Rumen Fluid After Fermentation of Crude Palm Oil (CPO) Protected by Liquid Smoke}

The results of the statistical tests shows that there are significant effects $(\mathrm{p}<0.01)$ of $\mathrm{CPO}$ protection by liquid smoke on SFAs, MUFAs, and PUFAs in rumen fluid after in vitro fermentation (Table 3). When compared between treatments, the SFAs in the CPO protected by $2.5 \%$ and $5.0 \%$ of liquid smoke, P1 and P2, were lower, while MUFA and PUFA were higher compared to the unprotected CPO (P0).

When compared to CPO without protection by liquid smoke (P0), after being fermented, CPO protected with $2.5 \%(\mathrm{P} 1)$ and $5 \%(\mathrm{P} 2)$ of liquid smoke had lower 
Table 1. The average fat profiles of crude palm oil (CPO) used in the study

\begin{tabular}{lcr}
\hline Fat profiles & Units & Compositions \\
\hline Iodium value & $\mathrm{g} \mathrm{I} 2 / 100 \mathrm{~g}$ & $36.27 \pm 0.03$ \\
Saponification value & $\mathrm{mg} \mathrm{KOH} / \mathrm{g}$ & $182.84 \pm 0.11$ \\
Acid value & $\mathrm{mg} \mathrm{KOH} / \mathrm{g}$ & $6.98 \pm 0.03$ \\
Peroxide value & $\mathrm{mg} \mathrm{KOH} / \mathrm{g}$ & $0.30 \pm 0.01$ \\
Fatty acid : & & \\
$\quad$ Caprylic & $\%$ & $0.08 \pm 0.05$ \\
Capric & $\%$ & $0.07 \pm 0.01$ \\
Lauric & $\%$ & $0.63 \pm 0.04$ \\
Myristic & $\%$ & $2.20 \pm 0.11$ \\
$\quad$ Palmitic & $\%$ & $54.71 \pm 0.49$ \\
$\quad$ Palmitoleic & $\%$ & $0.23 \pm 0.01$ \\
Stearic & $\%$ & $2.74 \pm 0.10$ \\
Oleic & $\%$ & $29.98 \pm 0.66$ \\
Linoleic & $\%$ & $8.09 \pm 0.35$ \\
Linolenic & $\%$ & $0.17 \pm 0.01$ \\
Arachidic & $\%$ & $0.15 \pm 0.00$ \\
SFAs & $\%$ & $60.42 \pm 0.43$ \\
MUFAs & $\%$ & $30.21 \pm 0.65$ \\
PUFAs & $\% .41 \pm 0.37$ \\
Total & $\%$ & $99.03 \pm 0.34$ \\
\hline
\end{tabular}

Note: SFAs= Saturated fatty acids, was calculated from Caprylic, Capric, Lauric, Myristic, Palmitic, Stearic; MUFAs= Monounsaturated fatty acids, was calculated from Palmitoleic, Oleic; PUFAs= Polyunsaturated fatty acids, was calculated from Linoleic, Linolenic, Arachidic; The total was calculated from the number of SFAs, MUFAs, PUFAs.

$(\mathrm{p}<0.01)$ SFAs by $10.47 \%$ and $2.61 \%$, respectively. CPO protected by $2.5 \%$ of liquid smoke (P1) had higher $(\mathrm{p}<0.01)$ MUFAs and PUFAs, by $5.81 \%$ and $5.27 \%$, respectively, while CPO protected by $5.0 \%$ of liquid smoke $(\mathrm{P} 2)$ had higher $(\mathrm{p}<0.01)$ MUFAs and PUFAs, by $2.37 \%$ and $1.51 \%$, respectively.

\section{Fermentation Characteristics and Rumen Microbial Activities}

The fermentation characteristics and rumen microbial activities of rumen fluid after fermentation of CPO protected by various concentrations of liquid smoke are presented in Table 4 . The results of the statistical tests showed that there were significant effects $(p<0.01)$ of $\mathrm{CPO}$ protection by liquid smoke on $\mathrm{NH}_{3^{\prime}} \mathrm{pH}$, and CMCase, but there was no significant effects on total VFA and microbial protein in rumen fluid during in vitro fermentation. CPO protected by $2.5 \%$ of liquid smoke had significantly higher $\mathrm{NH}_{3}, \mathrm{pH}$, and CMC-ase compared to control CPO without protection by liquid smoke and CPO protected by $5.0 \%$ liquid smoke.

When compared to $\mathrm{CPO}$ without protection by liquid smoke (P0), after fermentation, $\mathrm{CPO}$ protected by $2.5 \%$ liquid smoke (P1) had higher $\mathrm{NH}_{3}$ and CMC-ase activity by $10.43 \mathrm{mg} / 100 \mathrm{~mL}$ and $6.98 \mathrm{U} / \mathrm{g}$, respectively, compared to control CPO without protection of liquid smoke. When the level of liquid smoke increased to $5 \%$ (P2), $\mathrm{NH}_{3}$ content decreased by $0.72 \mathrm{mg} / 100 \mathrm{~mL}$, whereas CMC-ase activity only increased by $1.68 \mathrm{U} / \mathrm{g}$.
Table 2. Fatty acid composition (\%) of crude palm oil (CPO) before and after being protected by liquid smoke (before fermentation)

\begin{tabular}{lrrr}
\hline \multirow{3}{*}{ Fatty acids } & \multicolumn{3}{c}{ Treatments } \\
\cline { 2 - 4 } & \multicolumn{1}{c}{ P0 } & P1 & P2 \\
\hline Caprylic & nd & nd & nd \\
Capric & $0.09 \pm 0.00$ & $0.10 \pm 0.00$ & $0.10 \pm 0.01$ \\
Lauric & $0.68 \pm 0.04$ & $0.69 \pm 0.01$ & $0.71 \pm 0.07$ \\
Myristic & $2.26 \pm 0.13$ & $2.64 \pm 0.05$ & $2.96 \pm 0.16$ \\
Palmitic & $57.28 \pm 0.86$ & $56.67 \pm 0.14$ & $57.48 \pm 0.42$ \\
Palmitoleic & $0.21 \pm 0.00$ & $0.92 \pm 0.08$ & $0.34 \pm 0.10$ \\
Stearic & $2.53 \pm 0.11$ & $2.61 \pm 0.01$ & $2.52 \pm 0.10$ \\
Oleic & $28.82 \pm 0.71$ & $27.68 \pm 0.44$ & $27.78 \pm 0.28$ \\
Linoleic & $6.93 \pm 0.08$ & $6.51 \pm 0.03$ & $6.54 \pm 0.22$ \\
Linolenic & $0.16 \pm 0.00$ & $0.24 \pm 0.01$ & $0.18 \pm 0.02$ \\
Arachidic & $0.12 \pm 0.01$ & $0.11 \pm 0.01$ & $0.11 \pm 0.01$ \\
SFAs & $62.83 \pm 0.91$ & $62.71 \pm 0.22$ & $63.76 \pm 0.57$ \\
MUFAs & $29.03 \pm 0.71$ & $28.60 \pm 0.35$ & $28.12 \pm 0.38$ \\
PUFAs & $7.20 \pm 0.08$ & $6.86 \pm 0.04$ & $6.82 \pm 0.25$ \\
Total & $99.06 \pm 0.11$ & $98.16 \pm 0.10$ & $98.70 \pm 0.06$ \\
\hline
\end{tabular}

Note: $\mathrm{P} 0=\mathrm{CPO}$ without protection by liquid smoke; $\mathrm{P} 1=\mathrm{CPO}$ protected by $2.5 \%$ of liquid smoke; $\mathrm{P} 2=\mathrm{CPO}$ protected by $5.0 \%$ of liquid smoke; nd= not detected. SFAs= Saturated fatty acids, was calculated from Caprylic, Capric, Lauric, Myristic, Palmitic, Stearic; MUFAs $=$ Monounsaturated fatty acids, was calculated from Palmitoleic, Oleic; PUFAs= Polyunsaturated fatty acids, was calculated from Linoleic, Linolenic, Arachidic; The total was calculated from the number of SFAs, MUFAs, PUFAs.

\section{DISCUSSION}

\section{Lipid Profile and Fatty Acid Composition of Crude Palm Oil (CPO) before and after being Protected by Liquid Smoke}

The determination of fat profile (iodine number, saponification number, acid number, peroxide number, and fatty acid) of $\mathrm{CPO}$ reflects the quality of $\mathrm{CPO}$ used as a source of unsaturated fatty acids. Iodine value (or Iodine number or Iodine absorption value) is an essential characteristic of fat or oil, expressed by the number of grams of $\mathrm{I}_{2}$ that will react with double bonds in 100 grams of fat, oil, and wax (Yildiz et al., 2019). This variable is used to measure the degree of unsaturated bond in fats or oils (Famobuwa et al., 2016). The iodine value of CPO used in this research was $36.27 \mathrm{~g} \mathrm{I} / 100 \mathrm{~g}$. The Iodine value of $\mathrm{CPO}$, according to Malaysian standards, is $50.4-53.7 \mathrm{~g} \mathrm{I}_{2} / 100 \mathrm{~g}$ (Japir et al., 2017). The lower iodine value found in this study could be due to the lower content of UFAs, i.e., oleic (29.98\%), linoleic (8.09\%), and linolenic $(0.17 \%)$.

Saponification values represent the number of milligrams of potassium hydroxide, or sodium hydroxide needed to saponify $1 \mathrm{~g}$ of fat or oil, which indicates the molecular weight or length of the fat or oil chain that is present (Sharma et al., 2013). Oils or fats that contain fatty acids with short carbon chains have a relatively small molecular weight, so they have large saponification values and vice versa. The saponification value of $\mathrm{CPO}$ used in this research was $182.84 \mathrm{mg} \mathrm{KOH} / \mathrm{g}$. The saponification value of $\mathrm{CPO}$, according to Malaysian 
Table 3. The fatty acid composition (\%) of rumen fluid after fermentation of crude palm oil (CPO) protected by liquid smoke

\begin{tabular}{lccc}
\hline \multirow{2}{*}{\begin{tabular}{c} 
Fatty acids \\
\multicolumn{1}{c}{$(\%)$}
\end{tabular}} & \multicolumn{3}{c}{ Level of liquid smoke } \\
\cline { 2 - 4 } Caprylic & nd & P1 & P2 \\
Capric & nd & nd & nd \\
Lauric & $1.71 \pm 0.44^{\mathrm{a}}$ & $0.01 \pm 0.02^{\mathrm{b}}$ & $0.52 \pm 0.51^{\mathrm{b}}$ \\
Myristic & $6.25 \pm 0.76^{\mathrm{a}}$ & $5.08 \pm 0.35^{\mathrm{b}}$ & $4.65 \pm 0.47^{\mathrm{b}}$ \\
Palmitic & $56.42 \pm 0.87^{\mathrm{b}}$ & $53.61 \pm 1.85^{\mathrm{c}}$ & $59.95 \pm 1.39^{\mathrm{a}}$ \\
Palmitoleic & $0.16 \pm 0.16^{\mathrm{b}}$ & $2.72 \pm 0.31^{\mathrm{a}}$ & $0.13 \pm 0.23^{\mathrm{b}}$ \\
Stearic & $10.60 \pm 0.72^{\mathrm{a}}$ & $5.81 \pm 1.07^{\mathrm{c}}$ & $7.25 \pm 0.27^{\mathrm{b}}$ \\
Oleic & $11.79 \pm 1.20^{\mathrm{b}}$ & $15.03 \pm 0.68^{\mathrm{a}}$ & $14.17 \pm 1.03^{\mathrm{a}}$ \\
Linoleic & $5.55 \pm 0.52^{\mathrm{b}}$ & $8.70 \pm 0.65^{\mathrm{a}}$ & $5.77 \pm 0.52^{\mathrm{b}}$ \\
Linolenic & $1.15 \pm 0.42^{\mathrm{c}}$ & $3.27 \pm 0.45^{\mathrm{a}}$ & $2.44 \pm 0.47^{\mathrm{b}}$ \\
Arachidic & $\mathrm{nd}$ & $\mathrm{nd}$ & $\mathrm{nd}$ \\
SFAs & $74.98 \pm 1.13^{\mathrm{a}}$ & $64.51 \pm 2.79^{\mathrm{c}}$ & $72.37 \pm 1.20^{\mathrm{b}}$ \\
MUFAs & $11.94 \pm 1.33^{\mathrm{c}}$ & $17.75 \pm 0.38^{\mathrm{a}}$ & $14.31 \pm 1.02^{\mathrm{b}}$ \\
PUFAs & $6.70 \pm 0.27^{\mathrm{c}}$ & $11.97 \pm 1.03^{\mathrm{a}}$ & $8.21 \pm 0.78^{\mathrm{b}}$ \\
Total & $93.63 \pm 1.17$ & $94.23 \pm 3.95$ & $94.89 \pm 1.72$ \\
\hline
\end{tabular}

Note: $\mathrm{P} 0=\mathrm{CPO}$ without protection by liquid smoke; $\mathrm{P} 1=\mathrm{CPO}$ protected by $2.5 \%$ of liquid smoke; $\mathrm{P} 2=\mathrm{CPO}$ protected by $5.0 \%$ of liquid smoke; nd= not detected. Means in the same row with different superscripts differ significantly $(\mathrm{p}<0.01)$. SFAs= Saturated fatty acids, was calculated from Caprylic, Capric, Lauric, Myristic, Palmitic, Stearic; MUFAs= Monounsaturated fatty acids, was calculated from Palmitoleic, Oleic; PUFAs= Polyunsaturated fatty acids, was calculated from Linoleic, Linolenic, Arachidic; The total was calculated from the number of SFAs, MUFAs, PUFAs.

standards, is 194 to $205 \mathrm{mg} \mathrm{KOH/g}$ (Japir et al., 2017). The lower saponification number was caused by the high levels of MUFAs and PUFAs.

The acid value is the number ( $\mathrm{mg}$ ) of $\mathrm{KOH}$ required to neutralize free fatty acids present in $1.0 \mathrm{~g}$ of oil or fat. The acid value of CPO used in this research was $6.98 \mathrm{mg}$ $\mathrm{KOH} / \mathrm{g}$. The acid value of $\mathrm{CPO}$, according to Malaysian standards, is less or equal to $10.95 \mathrm{mg} \mathrm{NaOH} / \mathrm{g}$ (Japir et al., 2017). According to Chinedu et al. (2017), acid value of different palm oils in local factories in Imo State, Nigeria ranged from 20.76 to $37.59 \mathrm{mg} \mathrm{KOH} / \mathrm{g}$ with a mean of $28.30 \mathrm{mg} \mathrm{KOH} / \mathrm{g}$, while according to Abdulkadir \& Jimoh (2013), acid value of reference sample with the mean and standard deviation of its collected samples, respectively were $4.23 \mathrm{mg} \mathrm{KOH} / \mathrm{g}$ and $11.82 \pm 4.54 \mathrm{mg} \mathrm{KOH} / \mathrm{g}$. It shows that the CPO used in this study is still in the high quality.

Peroxide value is an index of the amount of fat or oil that has undergone oxidation. This peroxide value is significant for the identification of the level of fat or oil oxidation (Dermis et al., 2012). The results showed that the peroxide value of the CPO used in this study was $0.30 \mathrm{mg} \mathrm{KOH} / \mathrm{g}$. High peroxide numbers indicate fat or oil has been oxidized, which may be caused by the exposure to oxygen, light, and high temperatures.

From the results of this fat profile test, it can be seen that the CPO can be protected by liquid smoke because it has a relatively good quality, although it has a slight decrease in quality, especially in PUFA, which only decreased by $\pm 2.09 \%$. According to Mancini et al.
Table 4. Fermentation characteristics and microbial activity of rumen fluid after fermentation of crude palm oil (CPO) protected by liquid smoke

\begin{tabular}{lccc}
\hline \multirow{2}{*}{\multicolumn{1}{c}{ Items }} & \multicolumn{3}{c}{ Level of liquid smoke } \\
\cline { 2 - 4 } & \multicolumn{1}{c}{ P0 } & P1 & P2 \\
\hline Fermentation characteristics: & & \\
$\mathrm{NH}_{3}(\mathrm{mM})$ & $34.92 \pm 1.06^{\mathrm{b}}$ & $45.35 \pm 1.68^{\mathrm{a}}$ & $34.20 \pm 2.24^{\mathrm{b}}$ \\
VFA (mM) & & & \\
- Acetic & $13.80 \pm 1.58$ & $15.74 \pm 1.94$ & $14.45 \pm 1.07$ \\
- Propionic & $3.48 \pm 0.40$ & $4.15 \pm 0.84$ & $4.00 \pm 0.66$ \\
- Butyric & $1.37 \pm 0.29$ & $1.84 \pm 0.56$ & $1.70 \pm 0.45$ \\
- T-VFA & $18.65 \pm 1.70$ & $21.72 \pm 2.68$ & $20.15 \pm 1.29$ \\
- Ratio C2:C3 & $4.00 \pm 0.66$ & $3.87 \pm 0.61$ & $3.66 \pm 0.36$ \\
pH & $7.04 \pm 0.01^{\mathrm{b}}$ & $7.06 \pm 0.01^{\mathrm{a}}$ & $7.03 \pm 0.01^{\mathrm{b}}$ \\
Microbial activity : & & & \\
CMC-ase activity & $14.00 \pm 1.51^{\mathrm{c}}$ & $20.98 \pm 1.15^{\mathrm{a}}$ & $15.68 \pm 0.82^{\mathrm{b}}$ \\
(U/g) & & & \\
Microbial protein & $0.47 \pm 0.03$ & $0.50 \pm 0.07$ & $0.47 \pm 0.13$ \\
(mg/mL) & & & \\
\hline
\end{tabular}

Note: $\mathrm{P} 0=\mathrm{CPO}$ without protection by liquid smoke; $\mathrm{P} 1=\mathrm{CPO}$ protected by $2.5 \%$ of liquid smoke; P $2=\mathrm{CPO}$ protected by $5.0 \%$ of liquid smoke; nd= not detected. Means in the same row with different superscripts differ significantly $(\mathrm{p}<0.01)$.

(2015), the fatty acid composition of palm oil is $0.2 \%$ lauric, $1.1 \%$ myristic, $44.0 \%$ palmitic, $4.5 \%$ stearic, $39.2 \%$ oleic, $10.1 \%$ linoleic, $0.4 \%$ linolenic, and $0.1 \%$ arachidic, with total SFAs, MUFAs, and PUFAs of $49.9 \%$, 39.2\%, and $10.5 \%$, respectively. Based on this composition, especially for unsaturated fatty acids, the CPO used in this study had a lower content of oleic, linoleic, and linolenic by $9.22 \%, 2.01 \%$, and $0.23 \%$, respectively, which caused the content of MUFAs and PUFAs were also lower, by $8.99 \%$ and $2.09 \%$, respectively. It shows that before being protected by liquid smoke, the PUFAs of CPO used in this study decrease slightly, only $2.09 \%$. This decrease may occur during the storage process. According to Frank et al. (2011), deteriorative or decreasing quality in palm oil during storage are caused by the type of storage material, light, air, and autocatalytic hydrolysis by lipolytic microorganisms, and water content. According to Sampaio et al. (2011), CPO qualities are influenced by several factors, namely water and impurities, free fatty acids, peroxide value, saponification value, bleaching power, melting points, and heavy metal content. After being protected by liquid smoke before being fermented, SFAs in P0, P1, and P2 were increased, while MUFAs and PUFAs were decreased. When compared to P0, MUFAs in P1 and P2 decreased by only $0.43 \%$ and $0.91 \%$, while PUFAs in P1 and P2 decreased by only $0.34 \%$ and $0.38 \%$. The decreases of MUFAs and PUFAs during protection (before fermentation) are not essential; the most important thing is the effectiveness of the results of this protection during fermentation. The decrease of MUFAs and PUFAs might be caused by the addition of Prosteo skim milk in $\mathrm{CPO}$, thereby increasing SFAs (palmitic), but decreasing MUFAs (oleic) and PUFAs (linoleic). This condition may also be caused by water content in liquid smoke, which donates $\mathrm{H}+$ and 
is bound by double bonds in UFAs so that it becomes SFAs. This condition can be occurred before fermentation in the rumen, so it is not related to the process of lipolysis and hydrogenation of fatty acids. According to Baltes et al. (1981), the water content in liquid smoke is relatively high, around $20.3 \%$.

\section{The Fatty Acid Composition of Rumen Fluid after Fermentation of Crude Palm Oil (CPO) Protected by Liquid Smoke}

When compared among treatments, CPO protected by $2.5 \%$ of liquid smoke (P1) has lower SFAs with higher MUFAs and PUFAs compared to CPO without protection by liquid smoke (P0). The low SFAs may be caused by aldehydes (natural formaldehyde) in liquid smoke that bind very strongly to proteins in skim milk so that they protect fatty acids from the hydrogenation by rumen microbes. Decreased rumen microbial hydrogenation causes SFAs to decrease, due to the decreased lauric, myristic, palmitic, and stearic fatty acids concentrations. The CPO without protection by liquid smoke will be hydrogenated by rumen microbes into SFAs, especially stearic acid. As a result, most of MUFAs (70\% to $95 \%$ ) and PUFAs (85\% to $100 \%$ ) are hydrogenated to SFAs (stearic), so that stearic will increase, while oleic, linoleic, and linolenic acids will decrease in the rumen. The CPO protected by liquid smoke, is a source of UFAs and can reduce the hydrogenation process on oleic, linoleic, and linolenic, thus increasing MUFAs and PUFAs.

These results indicate that the use of liquid smoke containing aldehydes (natural formaldehyde) as a protector can protect CPO as a source of UFA. Aldehydes in the carbonyl group of liquid smoke will bind to amino acids in skim proteins, form strong bonds in the form of coagulation to protect fats, so it can reduce hydrogenation of UFA by rumen microbes, thereby increasing UFA in the rumen fluid. This result is in line with the result reported by Tiven et al. (2011b) that CPO protected with formaldehyde can reduce rumen microbial hydrogenation so increase oleic and linoleic acids. Formaldehyde and protein will form chemical bonds that are stable at neutral $\mathrm{pH}$ in the rumen but become unstable at acidic $\mathrm{pH}$ in the abomasum.

\section{Fermentation Characteristics and Rumen Microbial Activity after Fermentation of Crude Palm Oil (CPO) Protected by Liquid Smoke}

After fermentation of CPO protected by liquid smoke, fermentation characteristics and rumen microbial activity in P1 were higher compared to those in P0 and P2 indicating that rumen fermentation activity is going well. The high concentration of $\mathrm{NH}_{3}$ in the rumen is affected by protein content in the feed and the solubility of feed protein. In P1 and P2, the availability of the same feed protein is derived from skim milk, which is used as a protein source for the protection of feed fat. When the level of liquid smoke rises that binds to the protein, it causes the solubility of the protein to decrease. The protection of CPO with $2.5 \%$ of liquid smoke provides the optimal protein solubility for protein degradation, thereby increasing $\mathrm{NH}_{3}$ content. This condition is also thought to be caused by a high protein content that are easily degraded, resulting in a higher $\mathrm{NH}_{3}$ content in the rumen. High $\mathrm{NH}_{3}$ content in P1 causes the availability of Nitrogen $(\mathrm{N})$ in P1 to be higher compared to those in $\mathrm{P} 0$ and $\mathrm{P} 2$. The availability of $\mathrm{N}$ sources and $\mathrm{C}$ framework of T-VFA (which tends to be higher in P1) will be used by rumen microbes for the synthesis of microbial proteins. Therefore, microbial proteins tend to be higher in P1 $(0.03 \mathrm{mg} / \mathrm{mL})$ compared to those in $\mathrm{P} 0$ and $\mathrm{P} 2$. The higher availability of $\mathrm{NH}_{3}$ is also used for the growth and development of microbial cells so that CMC-ase activity in P1 is higher compared to those in $\mathrm{P} 0$ and $\mathrm{P} 2$.

When the liquid smoke level increases to $5 \%$ (P2), protein solubility decreases that eventually decreases the $\mathrm{NH}_{3}$ content. The decrease in $\mathrm{NH}_{3}$ content causes the decrease in the availabilities of $\mathrm{N}$ and $\mathrm{C}$ framework of T-VFA as an energy source, thereby reduce protein synthesis and CMC-ase activity in P2. This decrease may also be due to the anti-microbial properties of liquid smoke because it contains formaldehyde, thus affecting microbial activity in the rumen. This result is in line with the result reported by Tiven et al. (2012) that treatment of feed with formaldehyde significantly reduces $\mathrm{NH}_{3}$ content in the rumen fluid.

CPO protected by $2.5 \%$ of liquid smoke (P1) tends to increase VFA, namely acetate, propionate, butyrate, and total VFA (although they are not statistically significant). However, the increased in liquid smoke level to 5\% in P2 tended to decrease VFA. According to Hartati (2015), fat protection using formaldehyde did not significantly affect VFA content. This decrease may be caused by the increase in the liquid smoke concentration, thereby reducing microbial activity in degrading feed.

The $\mathrm{NH}_{3}$ content obtained in this study ranged from 342 to $453 \mathrm{mg} / \mathrm{L}$ (34.20 to $45.35 \mathrm{mg} / 100 \mathrm{~mL}$ ). According to Tiven et al. (2011a), the protection of CPO using technical formaldehyde (with different levels) produced $\mathrm{NH}_{3}$ content in the range of 134 to $227 \mathrm{mg} / \mathrm{L}$ (13.44 to $22.79 \mathrm{mg} / 100 \mathrm{~mL}$ ). The $\mathrm{NH}_{3}$ content in this study was also higher than that reported by Seradj et al. (2019) who tested alfalfa in vitro i.e., $307 \mathrm{mg} / \mathrm{L}$. The high $\mathrm{NH} 3$ concentration in CPO protected by $2.5 \%$ of liquid smoke (P1) might be due to the high protein content in skim milk with a good solubility that eventually increased feed degradation. According to McDonald et al. (2010), the range of optimum concentration of $\mathrm{NH}_{3}$ in the rumen is $85-300 \mathrm{mg} / \mathrm{L}$ and this range is highly depended on the degree of feed degradation.

The content of T-VFA in this study ranges between 18.65 to $21.72 \mathrm{mM} / \mathrm{L}$, while $\mathrm{CMC}$-ase activity ranges between 14.00 to $20.98 \mathrm{U} / \mathrm{g}$. This result is in line with the results reported by Tiven et al. (2011a) who protect CPO using technical formaldehyde (with different levels) and obtain an average T-VFA in the range of 19.53 to $32.77 \mathrm{mM} / \mathrm{L}$, while CMC-ase activity is in the range of 14.42 to $20.74 \mathrm{U} / \mathrm{g}$. According to McDonald et al. (2010), the optimum VFA content in the rumen are between 10 to $70 \mathrm{mM} / \mathrm{L}$, so it can be said that the $\mathrm{NH}_{3}$ content and T-VFA in this study (P0, $\mathrm{P} 1$, and $\mathrm{P} 2$ ) are within the nor- 
mal range. It shows that $\mathrm{CPO}$, as a source of unsaturated fatty acids which is protected by liquid smoke, has no negative effect on fermentation characteristics and rumen microbial activity after fermentation.

\section{CONCLUSION}

It can be concluded that the use of $2.5 \%$ liquid smoke is better in the protection of feed fats, because it can reduce hydrogenation, thereby increasing UFAs and has no adverse effect on fermentation characteristics and microbial activity in vitro. This research needs to be further tested in vivo to determine the effectiveness of liquid smoke as a fat protector on unsaturated fatty acids, fermentation parameters, and microbial activity.

\section{CONFLICT OF INTEREST}

We declare that there is no conflict of interest with any financial, personal, or relationships with other people or organizations related to the material used and discussed in the manuscript.

\section{ACKNOWLEDGEMENT}

Many thanks to Directorate of Research and Community Development of Directorate General of Strengthening Research and Development, Ministry of Research, Technology and Higher Education, through LPPM Unpatti, which has financed all of this research with Competency-Based Research, in accordance the Research Contract of Budget 2019, with Number: 310/ UN13.3/LT/LPPM/2019, May 02, 2019.

\section{REFERENCES}

Abdulkadir, A. G. \& W. L. O. Jimoh. 2013. Comparative analysis of physico-chemical properties of extracted and collected palm oil and tallow. Chem. Search J. 4:44-54.

Abuelfatah, K., A. B. Zuki., Y. M. Goh., A. Q. Sazili, \& A. Abubakr. 2016. Effects of feeding the whole linseed on ruminal fatty acid composition and microbial population in goats. Anim. Nutr. 2: 323-328. https://doi.org/10.1016/j. aninu.2016.10.004

Anggraini, S. P. A., \& S. Yuniningsih. 2017. Optimizing the usage of liquid smoke from coconut shells as natural preservative for fresh fish. IJCRG. 10: 14-20.

Behan, A. A., T. C. Loh., S. Fakurazi., U. Kaka., A. Kaka, \& A. A. Samsudin. 2019. Effects of supplementation of rumenprotected fats on rumen ecology and digestibility of nutrients in sheep. Animals. 9: 1-18. https://doi.org/10.3390/ ani 9070400

Baltes, W., R. Wittkowski, I. Sochtig, H. Block, \& L. Toth. 1981. Ingredients of smoke and smoke flavor preparations. In: The quality of foods and beverages (G. Charalambous \& G. Inglett). Academic Press. New York. pp. 1-19. https:// doi.org/10.1016/B978-0-12-169102-8.50007-6

Chinedu, E. E., E. C. Ebere, \& A. C. Emeka. 2017. Quality assessment of palm oil from different palm oil local factories in Imo State, Nigeria. WSN. 88:152-167.

Dermiş, S., S. Can \& B. Doğru. 2012. Determination of peroxide values of some fixed oils by using the mFOX method. Spectrosc. Lett. 45: 359-363. https://doi.org/10.1080/003870 10.2012.666702

Dymińska, L., M. Calik, A. M. M. Albegar, A. Zając, K. Kostyń,
J. Lorenc \& J. Hanuza. 2017. Quantitative determination of the iodine values of unsaturated plant oils using infrared and Raman spectroscopy methods. Inter. J. Food Properties. 20: 2003-2015. https://doi.org/10.1080/1094291 2.2016.1230744

Famobuwa, O. E., H. O. Oloyede, \& A. A. Agbowuro. 2016. Chemical changes in crude palm oil and refined palm kernel-oil employed in deep-frying. Pharm. Chem. J. 3: 1-7.

Frank, N. E. G., M. M. E. Albert, D. E. E. Laverdure, \& K. Paul. 2011. Assessment of the quality of crude palm oil from smallholders in Cameroon. J. Stored Prod. Postharvest Res. 2:52-58.

Gupta, V. K., R. Parsad, L. M. Bhar, \& B. N. Mandal. 2016. Statistical Analysis of Agricultural Experiments. Part-I: Single Factor Experiments. ICAR-Indian Agricultural Statistics Research Institute Library Avenue, Pusa, New Delhi.

Hadanu, R. \& D. A. N. Apituley. 2016. Volatile compounds detected in coconut shell liquid smoke through pyrolysis at a fractioning temperature of $350-420{ }^{\circ} \mathrm{C}$. Makara J. Sci. 20: 95-100. https://doi.org/10.7454/mss.v20i3.6239

Halliwel, G., N. N. B. A. Wahab, \& A. H. Patle. 1985. Chemical composition of endo 1,4- $\beta$-glucanase to cellulotic in Trichoderma koningii. J. App. Biochem. 7: 43-45.

Harfoot, C. G. \& G. P. Hazlewood. 1997. Lipid metabolism in the rumen. In: The Rumen Microbial Ecosystem. 2nd ed. Hobson PN and Stewart CS (eds). London: Chapman \& Hall, pp. 140-197. https://doi.org/10.1007/978-94-009-1453-7_9

Hartati. L., A. Agus, L. M. Yusiati, \& B. P. Widyobroto. 2015. Free fatty acid concentration and carboxymethyl cellulase activity of some formulas of protected fat-protein tested in vitro. Anim. Prod. 17:92-96. https://doi.org/10.20884/1. anprod.2015.17.2.513

Hatta, M., S. Baco, S. Garantjang, \& E. Abustam. 2018. Performance of Kacang Goat fattening intensive using complete feed with different levels of liquid smoke. Adv. Env. Biol. 12:17-20.

Japir, A. A., J. Salimon, D. Derawi, M. S. Bahadi, A. Shuja'a, \& M. R. Yusop. 2017. Physicochemical characteristics of high free fatty acid crude palm oil. OCL. 24: 1-9. https:// doi.org/10.1051/ocl/2017033

Jayanegara, A., S. P. Dewi, N. Laylli, E. B. Laconi, Nahrowi, \& M. Ridla. 2016. Determination of cell wall protein from selected feedstuffs and its relationship with ruminal protein digestibility in vitro. Med. Pet. 39: 134-140. https://doi. org/10.5398/medpet.2016.39.2.134

Li, D., J. Q. Wang \& D. P. Bu. 2012. Ruminal microbe of biohydrogenation of trans-vaccenic acid to stearic acid in vitro. BMC Research Notes. 5: 1-8. https://doi. org/10.1186/1756-0500-5-97

Liu, Y., S. Poon, E. Seeman, D. L. Hare, M. Bui, \& S. Iuliano. 2019. Fat from dairy foods and 'meat' consumed within recommended levels is associated with favorable serum cholesterol levels in institutionalized older adults. J. Nutr. Sci. 8: 1-8. https://doi.org/10.1017/jns.2019.5

Mancini, A., E. Imperlini, E. Nigro, C. Montagnese, A. Daniele, S. Orrù, \& P. Buono. 2015. Biological and nutritional properties of palm oil and palmitic acid: effects on health. Molecules. 20: 17339-17361. https://doi.org/10.3390/ molecules200917339

McDonald, P., R. A. Edwards, J. F. D. Greenhalgh, C. A. Morgan, L. A. Sinclair, \& R. G. Wilkinson. 2010. Animal Nutrition. $7^{\text {th }}$ Ed. Pearson, London.

Menke, K. H. \& Steingass, H. 1988. Estimation of the energetic feed value obtained from chemical analysis and in vitro gas production using rumen fluid. Anim. Res. Dev. 28:7-55.

Montazeri, N., A. C. M. Oliveira, B. H. Himelbloom, M. B. Leigh, \& C. A. Crapo. 2013. Chemical characterization of commercial liquid smokeproducts. Food Sci. Nutr. 
1:102-115. https://doi.org/10.1002/fsn3.9

Nielsen, S. S., Qian, M. C, \& Pike, O. A. 2019. Gas chromatography; Fat characterization. In : Food Analysis Laboratory Manual (Nielsen, S. S). $3^{\text {rd }}$ edition. Springer International Publishing, West Lafayette, IN, USA. p. 87-95; 185-192. https://doi.org/10.1007/978-3-319-44127-6_8

Nieto, G. \& G. Ros. 2012. Modification of fatty acid composition in meat through diet: effect on lipid peroxidation and relationship to nutritional quality - A review. In: Lipid Peroxidation. Intech, London. pp. 239-258. https://doi. org $/ 10.5772 / 51114$

Nugraheni, Z. M., Hintono, A \& Mangisah, I. 2015. Kandungan asam lemak tak jenuh telur akibat pemberian kayambang (Salvinia molesta) pada ransum ayam petelur. Anim. Agric. J. 4: 28-34.

Sampaio, K. A., R. Ceriani, S. M. Silua, T. Taham, \& A. J. A. Meirelles. 2011. Steam deacidification of palm oil. Food and Bioprod. Process. 89: 383-390. https://doi.org/10.1016/j. fbp.2010.11.012

Scott, T. W., L. J. Cook, K. A. Ferguson, I. W. McDonald, R. A. Buchanan, \& G. Loftus Hills. 1970. Production of polyunsaturated milk fat in domestic ruminants. Aust. J. Sci. 32: 291.

Seradj, A. R., H. Morazán, M. Fondevila, J. B. Liang, G. de la Fuente, \& J. Balcells. 2019. In vitro and in situ degradation characteristics and rumen fermentation products of Moringa oleifera harvested at three different ages. Trop. Anim. Sci. J. 42: 39-45. https://doi.org/10.5398/ tasj.2019.42.1.39

Sharma, H., R. Giriprasad, \& M. Goswami. 2013. Animal fatprocessing and its quality control. J. Food Process. Technol. 4: $2-5$.

Soliman, G. A. 2018. Dietary cholesterol and the lack of evidence in cardiovascular disease. Review. Nutrients. 10: 1-14. https://doi.org/10.3390/nu10060780

Suharti, S., D. N. Aliyah, \& Suryahadi. 2018. Karakteristik fermentasi rumen in vitro dengan penambahan sabun kalsium minyak nabati pada buffer yang berbeda. JINTP. 16: 56-64. https://doi.org/10.29244/jintp.16.3.56-64

Swenberg, J. A., B. C. Moeller, K. Lu, J. E. Rager, R. Fry, \& T. B. Starr. 2013. Formaldehyde carcinogenicity research: 30 years and countingfor mode of action, epidemiology, and cancer risk assessment. Toxicol. Pathol. 41: 181-189. https:// doi.org/10.1177/0192623312466459
Tiven, N. C., L. M. Yusiati, Rusman, \& U. Santoso. 2011a. Protection of unsaturated fatty acid in crude palm oil from sheep. Med. Pet. 34: 42-48. https://doi.org/10.5398/ medpet.2011.34.1.42

Tiven, N. C., L. M. Yusiati, Rusman, \& U. Santoso. 2011b. Minimize the hydrogenation of unsaturated fatty acid in the rumen with formaldehyde. Indo. J. Chem. 11: 43-47. https://doi.org/10.22146/ijc.21418

Tiven, N. C. 2012. Keuntungan metode pengambilan cairan rumen menggunakan Trokar dari aspek kesejahteraan ternak. Wartazoa. 22: 194-201. https://10.14334/wartazoa. v22i4.969

Tiven, N. C., L. M. Yusiati, Rusman, \& U. Santoso. 2012. Effect of crude palm oil protection on fermentation parameter and rumen microbial activity of male local lamb. Anim. Prod. 14: 141-146.

Tiven, N. C., L. M. Yusiati, Rusman, \& U. Santoso. 2013. Effect of crude palm oil protection with formaldehyde on hydrogenation of rumen fluid unsaturated fatty acid: Its effect on blood and meat fatty acid. Indo. J. Chem. 13: 142-148. https://doi.org/10.22146/ijc.21297

Tiven, N. C., L. M. Yusiati, Rusman, \& U. Santoso. 2015. The effect of CPO protected with formaldehyde on digestibility and performance of thin tail sheeps. Buletin Peternakan 39: 78-83. https://doi.org/10.21059/buletinpeternak.v39i2.6711

Tiven, N. C., I. P. Siwa, \& L. Joris. 2016. Effects of citrus hystryx as fat protector on unsaturated fatty acids, cholesterol and chemical composition of lamb meat. J. Indonesian Trop. Anim. Agric. 41: 45-49. https://doi.org/10.14710/jitaa.41.1.

Tiven, N. C. 2017. Minimization of unsaturated fatty acid hydrogenation in rumen with keffir lime (Citrus hystrix) leaves. Bulletin Anim. Sci.. 41: 265-270. https://doi.org/10.21059/ buletinpeternak.v41i3.17787

Tran, L. V., B. A. Malla, S. Kumar, \& A. K. Tyagi. 2017. Polyunsaturated fatty acids in male ruminant reproduction. A review. Asian-Australas. J. Anim. Sci. 30: 622-637. https://doi.org/10.5713/ajas.15.1034

Weatherburn, M. W. 1967. Phenol-hypochlorite reaction for determination of ammonia. Anal. Chem. 39: 971. https://doi. org/10.1021/ac60252a045

Yildiz, Y., M. A. Alfeen, \& B. Yildiz. 2019. Determination of iodine value in triisocetyl citrate (Citmol-316) by United Satates Pharmacopeia Hanus Method. IJCPS 72: 38-41. 